\title{
Chapter 26 \\ Spatial, Ecological and Social Dimensions of Assessments for Bivalve Farming Management
}

\author{
C. Bacher, A. Gangnery, P. Cugier, R. Mongruel, Øivind Strand, \\ and K. Frangoudes
}

\begin{abstract}
The general purpose of assessment is to provide decision-makers with the best valuable data, information, and predictions with which management decisions will be supported. Using case studies taken from four scientific projects and dealing with the management of marine bivalve resources, lessons learned allowed identifying some issues regarding assessment approaches. The selected projects also introduced methodological or institutional frameworks: ecosystem approach to aquaculture (EAA), system approach framework (SAF), marine spatial planning (MSP), and valuation of ecosystem services (ES).

The study on ecosystem services linked ES to marine habitats and identified ES availability and vulnerability to pressures. The results were displayed as maps of resulting potential services with qualitative metrics. The vulnerability value is an alternative to monetary valuation and, in addition to identifying the most suitable
\end{abstract}

\footnotetext{
C. Bacher $(\bowtie) \cdot$ P. Cugier

IFREMER, Centre de Bretagne, DYNECO-LEBCO, Plouzané, France

e-mail: cedric.bacher@ifremer.fr; philippe.cugier@ifremer.fr

R. Mongruel

IFREMER, Centre de Bretagne, Ifremer, UMR 6308, AMURE, Plouzané, France

e-mail: remi.mongruel@ifremer.fr
}

\author{
A. Gangnery \\ IFREMER, Station de Port en Bessin, Port en Bessin, France \\ e-mail: aline.gangnery@ifremer.fr \\ $\varnothing$. Strand \\ Institute of Marine Research, Bergen, Norway \\ e-mail: oivind.strand@imr.no \\ K. Frangoudes \\ Univ Brest, IFREMER, CNRS, UMR 6308, AMURE, IUEM, Plouzané, France \\ e-mail: katia.frangoudes@univ-brest.fr
}


areas for each type of ES, this metric allows identifying the management strategies that will most probably maintain or affect each individual ES.

The MSP example focused on bivalve farming activity and accounted for several criteria: habitat suitability, growth performance, environmental and regulation constraints and presence of other activities. The ultimate endpoint of such an approach is a map with qualitative values stating whether a location is suitable or not, depending on the weight given to each criterion.

In the EAA case study, the indicator was defined by the growth performance of cultivated bivalves in different locations. This indicator is affected by distant factors - e.g. populations of marine organisms competing for the same food resource, nutrient inputs from rivers, time to renew water bodies under the action of tidal currents. The role and interactions of these factors were assessed with a dynamical ecosystem model.

Examples illustrate that the assessment is often multi-dimensional, and that multiple variables would interact and affect the response to management options. Therefore, the existence of trade-offs, the definition of the appropriate spatial scale and resolution, the temporal dynamics and the distant effects of factors are keys to a policy-relevant assessment. EA and SAF examples show the interest of developing models relating response to input variables and testing scenarios. Dynamic models would be preferred when the relationship between input and output variables may be masked by non-linear effects, delay of responses or differences of scales.

When decision-making requires economic methods, monetary values are often of poor significance, especially for those ecosystem services whose loss could mean the end of life, and appear to be a comfortable oversimplification of reality of socioecological systems which cannot be summarized in single numbers. Alternative methods, such as the ones proposed in the SAF and ES examples, would preferably consider institutional analysis or multicriteria assessment rather than single monetary values.

Case studies also highlighted that credibility of assessment tools benefit from the association of stakeholders at different stages, among which: identification of the most critical policy issues; definition of system characteristics including ecological, economical and regulation dimensions; definition of modelling scenarios to sort out the most effective management options; assessment of models and indicators outputs.

\footnotetext{
Abstract in Chinese 摘要:总体而言, 进行评价的目的是为决策者提供最有效 的数据, 信息和预测, 从而支持管理决策的制定。通过四个关于海水双壳贝类 资源管理案例研究, 我们明确了关于评估中存在的问题。这些案例研究包含 了方法学和一些制度框架, 其中包括: 水产养殖生态系统方法 (EA), 系统管理 方法 (SA), 海洋空间规划 (MSP) 和生态系统服务价值评估 (ES)。

在生态系统服务价值评估 (ES) 的案例研究中, 我们将其与海洋生境联系起 来, 确认了生态系统价值评估的有效性和应对不同压力时的脆弱性。评估将 定性结果在地图上进行相应的展示。脆弱值是经济估值的替代参考, 除了为 每种类型的生态服务确定最适区域外, 脆弱性指标可以帮助我们确认管理策 略是否会对不同生态系统服务功能造成影响。
} 
海洋空间规划的案例研究侧重于双壳贝类养殖活动并考虑了几个条件:适 宜性评价, 生长情况, 环境和法规限制以及其他相关活动。海洋空间规划的最 终目的是绘制具有定性值的示意图, 根据标准的权重来确定地点是否适合进 行养殖活动。

在水产养殖生态系统方法案例研究中, 指标由不同地点养殖的贝类生长情 况来确定。这类指标同样受其他因素的影响, 例如与贝类进行食物竞争的其 他生物种群, 来自河流的营养物质输入, 潮汐作用下水体的更新时间等。我 们可以利用生态系统动态模型来评估这些因素的相互作用。

这些系统往往是多维的, 多个变量会相互影响, 并影响管理系统的选择。 因此, 各方面因素的协调与权衡, 适当的模型空间尺度和分辨率, 动态的时序 模拟和一些外部驱动因素是进行养殖规划和策略评估的关键。我们可以通 过模型开发将输入数据与结果相应联系起来。当输入和输出变量之间的联 系是非线性、或存在响应延迟以及尺度差异时, 动态模型的建立成为有效的 解决方法。

当决策制定需要进行经济效益评估时, 单纯的经济核算通常意义不大, 因 为生态系统服务功能难以通过简单的货币化进行全面概括, 某些生态功能的 缺失将意味着生态系统的崩溃。其它可供选择的评估方法, 例如在系统管理 方法和生态系统评估案例中的方法，也不应该仅仅考虑货币价值，应当进行制 度分析或者多因素综合分析。

评估工具的可靠性可以从不同阶段的利益相关群体获得提升，其中包括： 确定最关键的政策问题; 确定包括生态、经济以及政策法规等方面的系统特 征; 定义具体的模型场景以采取最有效的管理手段; 评估模型和指标的产出 成果。

Keywords Ecosystem services $\cdot$ Marine spatial planning $\cdot$ Ecosystem approach to aquaculture $\cdot$ System approach $\cdot$ Modeling $\cdot$ Stakeholder involvement

关键词 生态系统服务 - 海域空间规划 - 水产养殖生态系统方法 系统管理方法 ・ 模型模拟 ・ 利益相关者的参与

\subsection{Introduction}

Valuation of Ecosystem Services (ES) is one among several management frameworks, concepts and approaches that support the implementation of several legislative tools (Lonsdale et al. 2015). These frameworks have different scopes which have been extensively described in handbooks, and discussed and compared in international working groups (e.g. FAO, ICES). They all aim at improving the management of natural resources and refer more or less explicitly to the need for longterm actions to make the use of resources sustainable. In a position paper published by the Marine Board, Rice et al. (2010) also highlighted the multiple dimensions of science-policy integration for decision-making with respect to management of marine resources. Recommendations included the links between ecosystem 
services and management policies, and the need for science support to strategic environmental assessments, including socioeconomic factors.

The objective of this chapter is to show some specific examples taken from scientific projects and introduce some issues regarding the integration of knowledge and assessment tools, rather than to review existing literature. The term assessment is taken in a broad sense as a "formal effort to assemble selected knowledge with a view to making it publicly available in a form intended to be useful for decisionmaking" (Rice et al. 2010). Our selection of examples will highlight the spatial, ecological and social dimensions that have been addressed through assessments of bivalve-related activities within several management frameworks: the ecosystem approach to aquaculture, marine spatial planning, system approach, and ecosystem services. We first review below the general definitions of these frameworks.

Historically, Integrated Coastal Zone Management (ICZM) may be considered as one of the first frameworks which dealt with the difficulty to manage coastal human activities competing for the of use natural resources (including space). Quoting Pinot (1998), Cormier et al. (2013) defined the objective of ICZM as "the disposition of each coastal segment to the most appropriate business, according to decisions taken by the public authorities in light of scientific knowledge, thanks to which we can ensure consistency in the use (avoiding the adverse effects that would result in sterilization of the rich shores), and harnessing the energy of nature to serve our needs rather than abruptly counter the natural system". This definition introduces key concepts, which are overarching across all other frameworks: role of stakeholders, resolution of conflicts, sustainable use of the coastal zone, use of scientific knowledge, interdependency of activities, multiple social and biophysical dimensions - which are highlighted in the following definitions for each framework.

Aguilar-Manjarrez et al. (2010) have defined Ecosystem Approach to Aquaculture (EAA) as "a strategy for the integration of the activity within the wider ecosystem in such a way that it promotes sustainable development, equity, and resilience of interlinked social and ecological systems". They stated three main principles for aquaculture development: (1) no degradation of ecosystem functions and services beyond their resilience capacity; (2) improvement of human wellbeing and equity for stakeholders; and (3) consideration for other relevant sectors. They also emphasized that EAA applies at different scales: the farm, the waterbody and its watershed/aquaculture zone, and the global, market-trade scale.

Marine Spatial Planning (MSP) is a "process of analyzing and allocating parts of three-dimensional marine space to specific uses, to achieve ecological, economic, and social objectives that are usually specified through the political process; the MSP process usually results in a comprehensive plan or vision for a marine region" (Aguilar-Manjarrez et al. 2010). MSP is generally defined as a means to "create and establish a more rational organization of the use of marine space and the interactions between its uses, to balance demands for development with the need to protect the environment, and to achieve social and economic objectives in an open and planned way" (Douvere 2008). This applies to aquaculture development where planning is an important process, which is expected to stimulate and guide the evo- 
lution of the sector by providing incentives and safeguards, attracting investments and boosting development, while ensuring its long-term sustainability to ultimately contribute to economic growth and poverty alleviation (Brugère et al. 2010).

The System Approach Framework (SAF) builds upon the systems science and aims to incorporate the ecological, social, and economic dimensions of coastal systems and integrate knowledge, to support decision-making (Tett et al. 2011). Dynamic models have been developed and used to explore alternative policy options following a problem-oriented and scenario-based approach. This approach involves several steps: consultation of stakeholders to prioritize one management issue; definition of the natural, social, and economic dimensions of the coastal system; building a mathematical model of the ecological and social processes likely to explain the dynamics of the system; defining scenarios and indicators to analyze model outputs with stakeholders.

Following MEA (2005), Ecosystem Services (ES) are defined as the benefits people obtain from ecosystems and include provisioning services such as food, water, and raw materials; regulating services such as climate regulation, protection from floods and storms, water quality and waste bioremediation; cultural services that provide recreational, aesthetic, and spiritual benefits; and supporting services such as biologically mediated habitats and nutrient cycling (Liquete et al. 2013).

To allow comparisons and discussions, the case studies described below are presented with a similar structure: issue identification, system definition, assessment principles, main results and lessons learned. On this basis, we review some of the key issues and features of the assessment: system boundaries, stakeholder involvement, tools availability, contribution to the decision-making process. All these examples deal with spatial aspects but more generally deal with multiple dimensions in relation to the questions raised and the framework used.

\subsection{Ecosystem Approach to Aquaculture - Bay of Mont Saint Michel Case}

\subsubsection{Issue Identification}

Mont Saint Michel Bay is a place of major bivalve farming in the northwestern part of France with an annual production of around 10,000 tonnes of the blue mussel Mytilus edulis, 5000 tonnes of the Pacific oyster Magallana gigas and 1000 tonnes of the European flat oyster Ostrea edulis. At the beginning of the 2000s, farmers requested a spatial extension of their concessions to avoid excessive siltation (in oyster areas) or growth limitation (in mussel areas). Furthermore, the industry has been responsible for the introduction of the invasive gastropod, Crepidula fornicata, the slipper limpet, through the importation of M. gigas during the 1970s (Blanchard 1997). Since then, the slipper limpet proliferated in the subtidal area of the bay to reach a biomass of ca. 150,000 tonnes in 2004 (Blanchard 2009), corresponding to 
the highest biomass of filter feeders in the bay. The carrying capacity of the bay has thus become an important question for scientists and stakeholders, especially farmers. These issues have been addressed through the IPRAC ${ }^{1}$ national project.

\subsubsection{System Definition}

Mont Saint Michel Bay is a sandy and muddy bay of $500 \mathrm{~km}^{2}$ with a high tidal range (up to $15 \mathrm{~m}$ ) and a large intertidal zone reaching half of the total surface area. The ecosystems and landscapes of the bay represent a remarkable natural and cultural heritage, subject to numerous protection measures, but also support a wide variety of human activities: bivalve farming, professional and recreational fishing, hunting, tourism, sheep farms on salt meadows or intensive farming on polders. An ICZM approach has been initiated by local authorities to build a shared vision of the bay and to define common and future management objectives.

\subsubsection{System Assessment}

From an ecological perspective, primary productivity, ecosystem carrying capacity and trophic interactions between natural and cultivated filter feeders have been investigated as well as the economic drivers of the aquaculture activity.

A numerical ecosystem model of the Mont Saint Michel bay has been developed, which couples a 3D hydrodynamic model to a primary production model and to a benthic model (Cugier et al. 2010a). The primary production model allows a realistic simulation of phytoplankton dynamics; the benthic model takes into account the main filter feeders present in the bay and the interactions between primary production and the ecophysiology of cultivated oysters and mussels.

This model was used as a tool to better understand the functioning of the bay, mediate stakeholder interactions, and co-construct scenarios of future changes. The stakeholders involved were local administrations, watershed managers, farmers, environmental non-governmental organizations, and recreational fishing representatives. A participatory approach was implemented to achieve this objective. A first series of meetings were organized to inform stakeholders about the scientific consortium, the modelling tool, its possibilities and limits, and get the perception of stakeholders regarding the trophic resource availability and sharing in the bay. Following that, a second series of meetings based on focus groups allowed the definition of a list of scenarios. These groups highlighted three categories of questions corresponding to more than 30 scenarios:

\footnotetext{
${ }^{1}$ IPRAC - Impact of environmental factors and shellfish culture practices on the ecosystem of Mont Saint Michel Bay and shellfish production. Study through modelling scenarios (2007-2010).
} 
- The link between watersheds and the bay through nutrient inputs to test potential effects on primary resource availability and bivalve production. Various scenarios have been proposed e.g. reduction in nutrient inputs, linked to EU Directive 2000/60/EC (European Community 2000), also known as Water Framework directive (WFD), or national regulations; increase of nutrient inputs based on the hypothesis of agriculture development.

- The proliferation of $C$. fornicata to investigate the potential trophic competition with other wild and cultivated filter feeders. Related scenarios explored further proliferation and control measures to limit it.

- Evolution of the shellfish farming practices (changes in standing stocks and/or variations in cultivated areas) and their possible effect on trophic resource availability.

Results of modelling scenarios were interpreted in terms of growth performance of cultivated species.

\subsubsection{Main Results}

Apart from scenarios dealing with aquaculture management, scenarios concerning proliferation of $C$. fornicata appear to have the most potential impacts in terms of trophic competition (Fig. 26.1; Cugier et al. 2010b). Objectives for reduction of nitrogen inputs from watersheds, as stated by the WFD or national directives, have a moderate impact on primary production in the bay and thus on bivalve production. In the first meetings with stakeholders, this reduction was not necessarily viewed as "a good thing", especially by bivalve farmers who expected a potential risk of

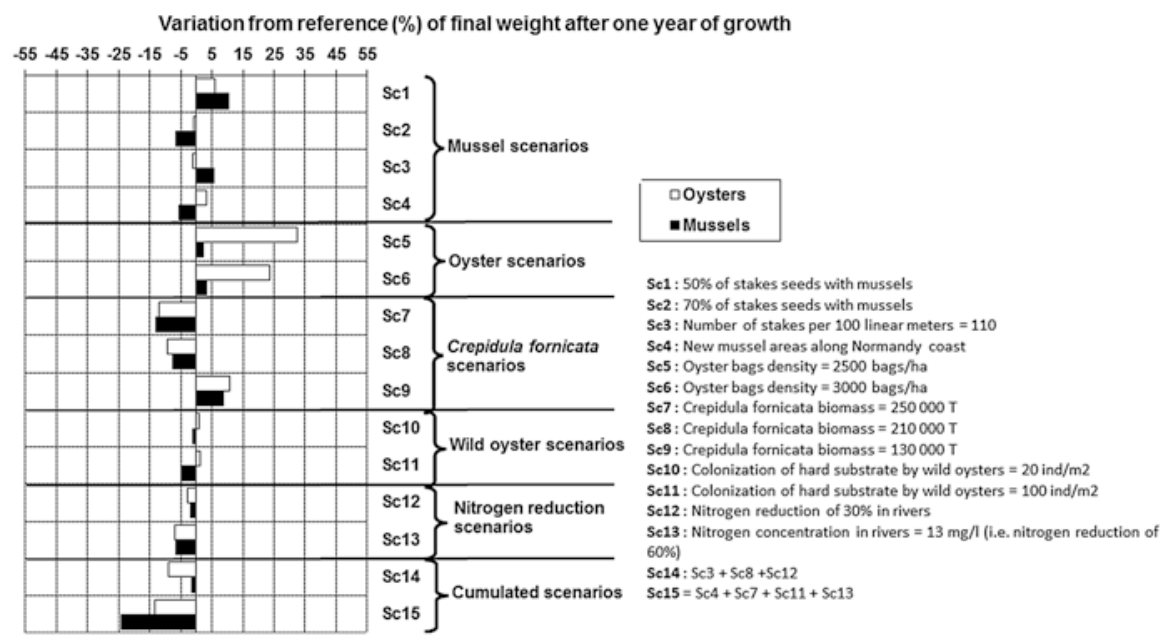

Fig. 26.1 Results of scenarios tested with the model of Bay of Mont Saint Michel. (Cugier et al. 2010b) 
growth performance decrease. Results show that this risk remains very limited, far behind the one related to $C$. fornicata proliferation. Finally, scenarios exploring farming practices modifications show a potential significant impact on food availability and bivalve growth. This result can be interpreted as a potential control lever to compensate for the negative effect due to $C$. fornicata.

\subsubsection{Lessons Learned}

The tested scenarios are neither predictive (they do not state the ecological future of the bay) nor normative (they should not be considered as real wishes concerning the evolution of the bay and what should be done or not). They are exploratory and designed to understand system dynamics and responses to more or less strong variations of its forcing functions. In this context, stakeholders perceive the model as a powerful tool with which "everything is possible". Stakeholders would use scenario results to prioritize the various forcing functions and their variations according to their impact on the trophic resource and the management objectives of this resource as set by themselves. They could be included into ongoing consultation processes at the bay and watershed levels.

\subsection{Marine Spatial Planning - Normandy Case}

\subsubsection{Issue Identification}

Normandy is located in the northwestern part of France and includes the bay of Mont Saint-Michel and also Cancale Bay (the latter does not belong to the Normandy Region, but lies in the same ecoregion). In response to the EU Directive on Marine Spatial Planning (MSP), the French government has set up a management plan at the scale of the four coastal regions (East Channel - North Sea for Normandy and North Atlantic - West Channel for Cancale Bay). The aquaculture (essentially bivalve) sector is also driven by specific spatial planning policy.

Linking social demand and scientific progress to develop operational tools for decision-makers and stakeholders has recently been identified as an important issue (Byron et al. 2011). On the one hand, MSP should be based on an ecosystem approach and must rely on the best scientific knowledge, research and innovation. One the other hand, scientists have developed expertise in Geographic Information Systems (GIS), remote sensing data and numerical modelling, which are well recognized as powerful tools to assist the development and management of sea use and the sustainable management of living resources. This issue was addressed through the AquaSpace ${ }^{2}$ project.

\footnotetext{
${ }^{2}$ Making space for increased aquaculture production - http://www.aquaspace-h2020.eu (2015-2018).
} 


\subsubsection{System Definition}

The whole length of the case study coastline is about $450 \mathrm{~km}$ for a total area of $20,000 \mathrm{~km}^{2}$ (including terrestrial and marine zones). The case study belongs to two administrative regions but also contains two biological entities: a part of the Gulf Normand Breton located on the Western part of the Cotentin peninsula and the Bay of Seine located on the Eastern part. Normandy represents a series of economic, cultural and environmental issues due to a large range of activities (e.g. bivalve farming, tourism, commercial and recreational fishing, agriculture, nuclear power plant, fuel processing industries, sand and gravel extraction and, in the future, offshore renewable energy) and a complex governance system based upon several administrations (AAMP 2009). In this area, bivalve aquaculture largely dominates aquaculture and is usually located in sheltered and intertidal areas (bays, estuaries). Two species are cultivated: the oyster $M$. gigas, and the mussel $M$. edulis with annual productions around 34,000 and 29,000 tonnes, respectively.

\subsubsection{System Assessment}

A web based dynamic GIS tool named AkvaVis (www.akvavis.no), developed by the Institute of Marine Research, Christian Michelsen Research and Hordaland County Council in Norway, has been deployed and adapted to the Normandy case. It allows the integration of data, model outputs, regulatory frameworks, and expert knowledge by applying a web-based dialogue where the user would receive instant response from the tool to any choice requested from the tool. Under the name of SISAQUA, ${ }^{3}$ Akvavis is mainly targeting the development of bivalve aquaculture in Normandy. Through the definition of spatial indicators of aquaculture suitability, it aims at helping end-users and decision-makers to optimize aquaculture performance (e.g. maximize individual growth, control water quality, rearrange existing bivalve culture areas) and to develop aquaculture activities (e.g. selecting new potential sites).

A working group has been set up to associate the main stakeholders (e.g. national, regional and local authorities, aquaculture industry and representatives, technical centers, non-governmental organizations, public institutions). The objectives were to engage a consultation and conciliation process around the issues related to aquaculture development in Normandy and the data needed to implement aquaculture MSP. This group is also being used to test and improve the SISAQUA tool (Fig. 26.2).

\footnotetext{
${ }^{3}$ Spatial Information System for Aquaculture in Normandy.
} 


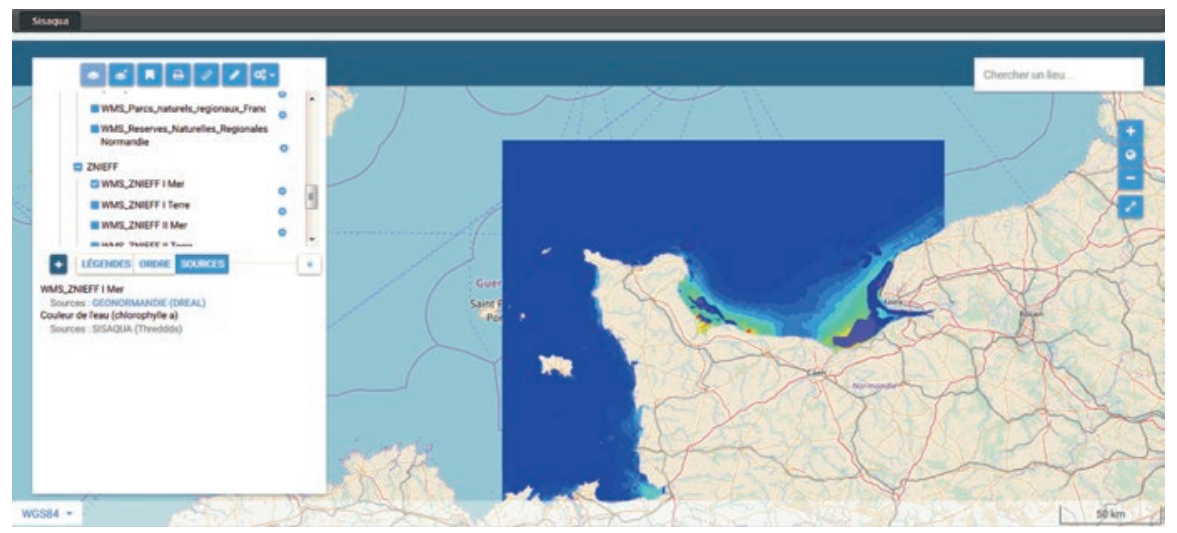

Fig. 26.2 Snapshot of SISAQUA showing maps of predicted mussel shell length and areas with specific protection measures. (http://sextant.ifremer.fr/fr/web/sisaqua)

\subsubsection{Main Results}

Group work allowed the identification and ranking of different types of issues regarding: policy and management, economic and market, aquacultureenvironmental issues, data and demand for tools.

With respect to indicators of site suitability for bivalve aquaculture, SISAQUA displays and combines spatial information related to:

- Physical and biological characteristics of the site based on observed data and outputs of hydrobiological models;

- Potential bivalve growth performance based the assimilation of remote sensing data in ecophysiological model;

- Public information on various regulations and other marine activities.

\subsubsection{Lessons Learned}

Based on the AkvaVis development in Norway over several years, and the ongoing work with SISAQUA in Normandy, several concerns have been raised:

(i) Data quality and integration. The user output of these systems fully relies on the quality of data used and the integration with other information from the regulatory framework, industry practice etc. Information outputs are characterized by a spatial and sometimes also temporal dimension, which requires data with a certain level of continuity, often from modelling. One issue is to be able to match data of different characteristics with, e.g. regulatory information, to make them assessable and significant for user application and analysis. For 
instance, physical data integrated in SISAQUA (such as waves or currents) are constrained by the extent of the hydrobiological model used, which does not presently include all the Normandy region. The quality of data provided relates also to the question how the update should be taken into account, often needed in cases with dynamic processes like rapid development of the aquaculture industry in extent or structure.

(ii) Stakeholder interactions. The development of GIS tools like AkvaVis/ SISAQUA is based on a demand for helping in analysis and decision-making. The experience showed that various stakeholders need to be involved in different stages of the process, to establish a dialogue and maximize chances to avoid possible conflicts. Stakeholders needed at an early stage of the process might not be of relevance for later stages. Strong stakeholder consultations through the development stages may also provide information needed for an efficient evaluation, for instance by user inquiry at completion. The process also highlights the necessity to avoid sectoral approaches when applying marine spatial planning. In AquaSpace, a stakeholder group was set up since the beginning of the project to create a framework for discussions and improve the tool development.

(iii) Tool limitations. AkvaVis, like SISAQUA, was constructed for the purpose of aquaculture development. Beyond limitations related to purely technical aspects, experience gained through AquaSpace showed that stakeholder demands are diverse, and that tools taking into account the links and interactions between sectors are needed.

\subsection{System Approach Framework - Pertuis Charentais Case}

\subsubsection{Issue Identification}

The Pertuis Charentais area is located on the French Atlantic coast. This site is characterized by the vulnerability of the continuum between the freshwater from the Charente catchment, a flat hydrological basin with a pluvial regime, and the coastal waters, which are subject to varying salinity gradients. Much of the human activities in the area require freshwater: availability of drinking water for households and tourists; good ecological status of the coastal ecosystems (rivers, saltmarshes, nurseries, coastal water productivity); agriculture (irrigation during summer for crop); shellfish farming (freshwater supports spat production and river nutrients support oyster growth). The local governance system implements regulations and management measures to maintain freshwater quality and sustainable levels of extractive use, while giving priority to the availability of freshwater for natural habitat protection and for consumption of drinking water. Nevertheless, the Charente watersheds frequently experience an acute summer freshwater deficit due to low rainfall and 
excessive irrigation. The research project SPICOSA ${ }^{4}$ addressed these freshwater management issues through the development of a System Approach Framework (SAF) for coastal zone management using virtual and simulation models in order to provide integrated assessments of the coastal zone (Tett et al. 2011).

\subsubsection{System Definition}

A focus group of local administrators involved in the Charente catchment management worked with the scientists in order to refine the definition of the issue at stake. According to the current management plan, Reachable Discharge Thresholds (RDT), which are supposed to guarantee the first two priorities (good ecological status of natural habitats and availability of drinking water for households), have been defined at different control points in the river catchment. The operational objective of the management plan ensures that the system can reach the RDTs during the summer in at least eight years out of ten. The stakeholder group's main expectations concerned the options available for achieving the already fixed objectives of this management system. The project thus focused on the quantitative management of the freshwater in the Charente catchment.

The Ecosystem Services (ES) approach was then used for depicting the user conflicts generated by the scarcity of freshwater in the Charente catchment. Four main conflicts are generated by the competing uses of the freshwater services in the catchment, the last two being classic cases of common-pool resource rivalries: (1) conflict between the two extractive uses of freshwater (irrigation and drinking water); (2) conflict between extractive uses (provisioning services) and other services (support, regulatory, and cultural) provided by freshwater; (3) rivalry among land farmers, who are direct users of freshwater; and (4) rivalry among farmers, who are indirect users of nutrients supplied by the river to the coastal waters. A model was built to simulate the impact of governance scenarios on the availability of freshwater for all uses (Mongruel et al. 2011).

\subsubsection{System Assessment}

A model of the social-ecological system has been set up in three tiers, which are interconnected through endogenous processes: resources and ecological functions (Charente hydrology and coastal water productivity), uses (agriculture, household drinking water consumption and bivalve farming) and governance mechanisms (water discharge thresholds and water use restrictions) (Fig. 26.3). The Charente river dynamics is represented by the equations of the hydrological model, which is

\footnotetext{
${ }^{4}$ Science and Policy Integration for Coastal Systems Assessment (2007-2011).
} 


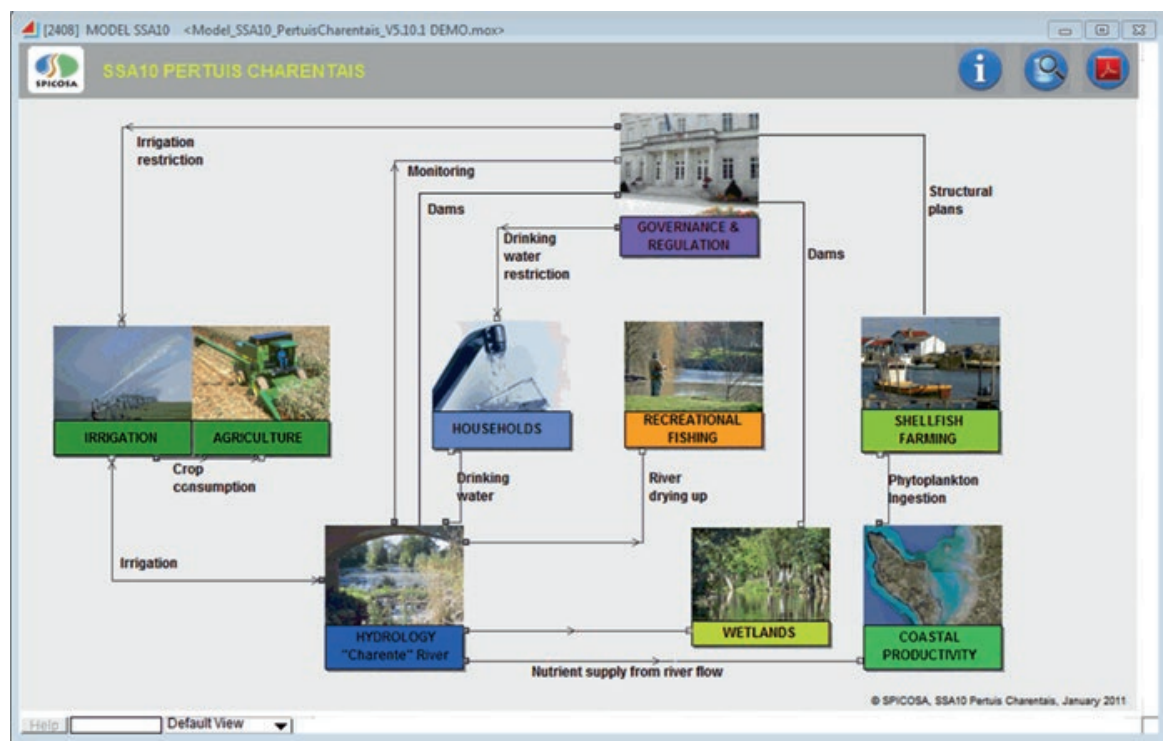

Fig. 26.3 System modelling framework as shown in the model user interface. (From Mongruel et al. 2011)

used by water managers to monitor the daily flow levels of the Charente and restrict irrigation during droughts. The agriculture module is connected to the hydrological sub-model and simulates crop water consumption under various irrigation strategies. These strategies depend on the institutional arrangements chosen in the governance module, which also simulates restriction rules triggered by critical discharge levels at monitoring stations. The model was able to estimate several indicators of the level of the main ecosystem services according to various climate and governance scenarios.

The assessment focused on the institutional arrangements regarding the freshwater use-rights of the land farmers. Downstream farmers have access to their whole annual use-right at any time. The restrictions imposed by water shortages apply to this annual use-right: farmers are likely to adopt short-sighted irrigation strategies because they have no incentive to anticipate future reductions of their permitted volumes, which are far higher than their actual needs. Farmer strategies in six of the upstream sub-basins are based on a planned schedule of irrigation needs that distributes annual use-rights over segmented periods of the irrigation season (periodic strategy). Some upstream farmers have adopted collaborative irrigation strategies for severe drought situations by taking turns to pump water in some locations (collaborative strategy). The simulations have explored the gradual harmonization of the irrigation schemes at river catchment scale, under various climate conditions. 


\subsubsection{Main Results}

The results indicate that any attempt to preserve coastal ecosystems through irrigation practices that consume less water would also probably mean productivity losses for farming of arable land. However, when achieved through "soft" institutional change, significant positive effects on the environment (expressed in terms of crisis event reduction) would generate fairly reasonable decreases in irrigation consumption. Coastal productivity is much more sensitive to inter-annual changes in precipitation than to the institutional arrangements regarding freshwater use. Intermediate production (half-grown oysters) is much more sensitive to the availability of primary production than the harvested production, and may decrease by $24 \%$ during a dry year. As improved irrigation strategies have no positive effect on their production during normal years, this may explain why oyster farmers prefer to concentrate their demands on the possibility of obtaining freshwater releases during severe droughts.

Protecting the ecosystems that depend on the Charente has been defined as the primary objective of water governance, an objective considered to be achieved when crisis situations due to an unbalanced water budget are avoided eight years out of ten. This "zero crisis" criterion is much more likely to be met during normal years than during dry years. The results of the simulation model suggest two directions for improved freshwater governance: (i) implementing planned individual strategies on the downstream area is a necessary condition for avoiding crisis events during normal years, and (ii) the most efficient institutional scheme for all climatic conditions would be to implement collaborative strategies in the entire river catchment.

\subsubsection{Lessons Learned}

Governance scenarios for coastal system assessments should pay attention to the complexity of institutional change. Most of the models for coastal system assessment simulate the introduction of a new management measure without considering the impact of existing measures and their evolution. The SPICOSA experiment in the Charente river catchment addressed "soft" institutional change, in which improved operational agreements, based on local collective organization, are taken into consideration, rather than more drastic change through top-down decisions.

The outputs of the simulations are expressed in terms of ES' physical availability and of production yield (for provisioning services), which is a first step toward estimates of costs, benefits, and their distribution. It is worth noting that, for collaborative institution analysis, transaction costs should also be taken into account, since these costs may discourage the emergence of effective partnerships (Lubell et al. 2002).

From a broader perspective, when the sustainability of a complex common-pool resource is at stake, some users may develop adaptive strategies by searching for 
alternative resources in external areas: this is already true for oyster farmers of the Charente region, who carry out the early stages of the growth cycle in other production basins. Such strategies may indicate decreasing robustness of the socialecological system, since adaptive behaviours prefer solutions other than collective action against resource overexploitation (Anderies et al. 2004).

\subsection{Valuation of Ecosystem Services - Normand-Breton Gulf Case}

\subsubsection{Issue Identification}

The Normand-Breton Gulf (NBG) encompasses a variety of natural habitats and marine ecosystems, which make it a candidate for the creation of Marine Protected Area (MPA). For this kind of large ecosystems with multiple issues (see also EA and MSP case studies), the French Administration has created a conservation and management tool called 'Marine Natural Park' which combines a series of objectives regarding knowledge improvement, habitat and species conservation, preservation of environmental quality, sustainable development of economic activities and cultural identity of the territory. VALMER ${ }^{5}$ was a French-British project which aimed at developing approaches for marine ES assessment in support of marine ecosystem management. In this project, the objective of the ES assessment was to provide an initial diagnosis of the area, in order to help future MPA managers to elaborate their management plan.

\subsubsection{System Definition}

The size of the whole area includes the Normandy and Brittany coasts, and covers a number of marine habitats and islands, totaling ca. $9971 \mathrm{~km}^{2}$. It is characterized by a landscape of various habitats: tidal flats, rock plates, and subtidal regions with a depth of up to $80 \mathrm{~m}$ (Cabral et al. 2015). Bivalve farming is one activity among many others (see MSP case study). These activities contribute to the economy of the region, which is populated by ca. 600,000 inhabitants who live at a distance less than $3 \mathrm{~km}$ from the coastline. Cabral et al. (2015) aimed to estimate the vulnerability of marine habitats as a proxy of their potential to deliver ES according to different management scenarios. The approach relies upon the assumption that the increase of vulnerability is likely to decrease the supply of ecosystem services.

\footnotetext{
${ }^{5}$ Valuing ecosystem services in the Western Channel (2012-2015).
} 


\subsubsection{System Assessment}

The concept of vulnerability considers the degree of exposure to environmental changes, the sensitivity of the natural system to these changes and the adaptive capacity of human systems. The assessment was built upon a combination of spatial information dealing with marine habitat characteristics and pressures related to the main human activities. Expert knowledge and habitat maps were combined to build a risk map using the InVEST habitat risk assessment model (HRA). The model output is a map of relative values showing the habitats, which are more or less sensitive to changes. This step was completed with a matrix of the potential contribution of each habitat to the main ecosystem services. Again, the output can be displayed as map of more or less high availability of a given ES. The final step of this method considers that a high level of ES availability makes a given habitat less vulnerable to a given risk. ES availability is then defined as a proxy of adaptive capacity. The ratio between habitat risk and ES availability yields a spatial vulnerability index, which is a qualitative measure of the habitat's ability to deliver ES, taking into account the level of pressure on the habitat. On this basis, theoretical management scenarios considered the increase or decrease of human pressure (e.g. conservation, development) and the vulnerability index was recalculated for each ES category. The map of vulnerability index changes for each ES type highlighted which areas are most sensitive to management actions, with respect to ES. Results can also be summarized as an average percentage of ES delivery change for a given habitat.

\subsubsection{Main Results}

In this study, bivalve shellfish farming is one among provisioning services and its importance is balanced by the amount of other services measured as the percentage of occupied habitat. The Habitat Risk Assessment model identified which habitats are the most important for the supply of ES, considering the usual classification of ES (Fig. 26.4). Simple theoretical scenarios were used to help understanding of potential degradation or improvement resulting from management options. For instance, results showed that the near shore areas exhibit higher risk values to various ES, which means that these habitats are more exposed to pressures unlike the habitats in the offshore areas (Cabral et al. 2015).

\subsubsection{Lessons Learned}

The HRA model was chosen because it allowed using available data and expert knowledge to define proxies of ES availability and relation to pressures. Model outputs are qualitative and can be used to identify the direction of relative changes 

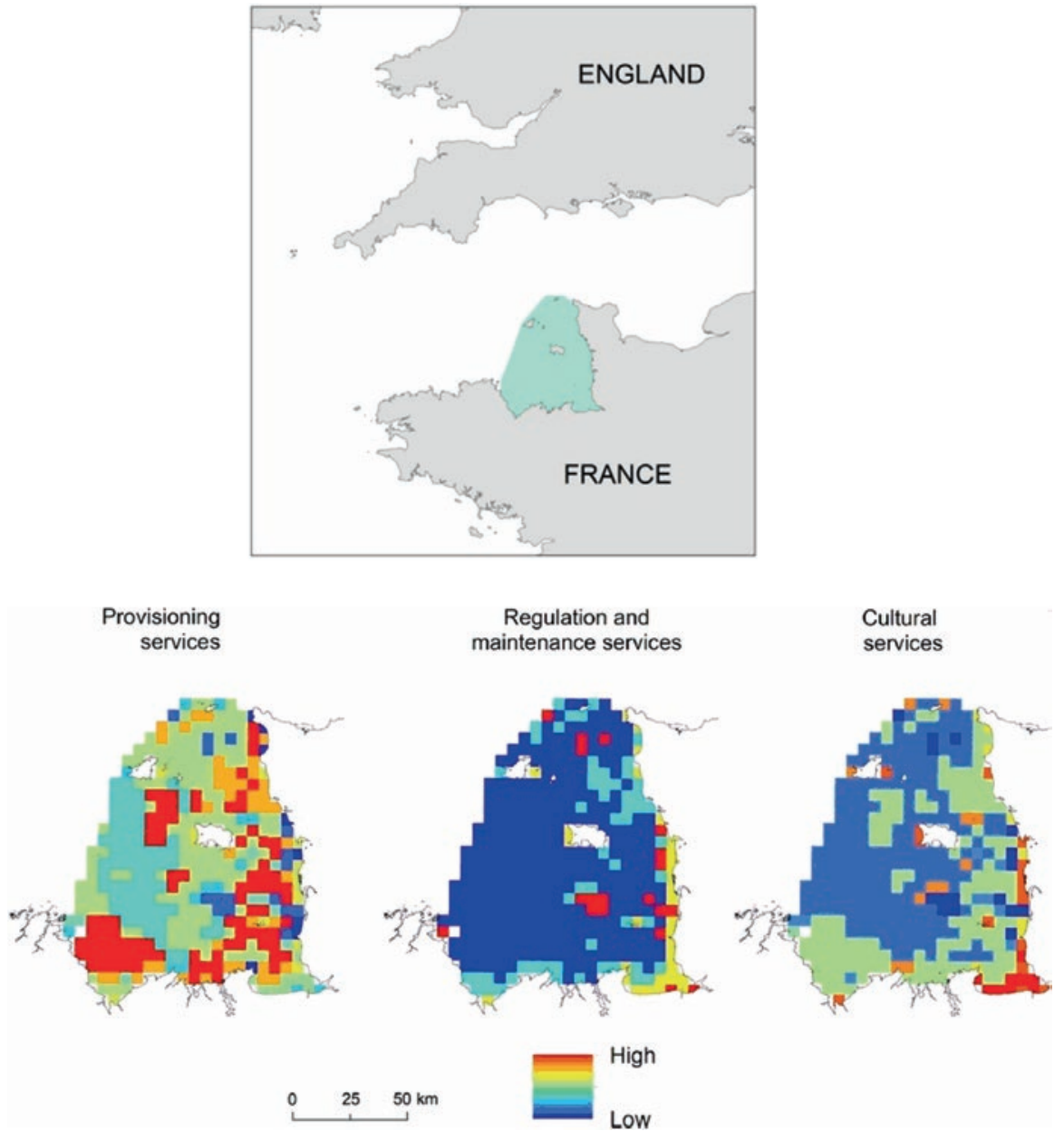

Fig. 26.4 Map of ES availability for different types of service. (From Cabral et al. 2015)

in ES supply when management scenarios are defined. As such, the results were only published to demonstrate and evaluate the applicability of the HRA method in the NGB context. The utility for decision-making has still to be tested and discussed with stakeholders.

Cabral et al. (2015) highlighted several difficulties and limitations. Among the most important ones, the quality and availability of reliable data is critical. Though a large effort was accomplished to gather and integrate existing information, input data were not always accurate and no validation of the results was possible. The approach was still not efficient for estimating regulating services, which cannot rely upon the classification of benthic habitats and would require more relevant information (e.g. pelagic ecosystem component). 


\subsection{Discussion}

\subsubsection{Assessment, Scale and Management}

The purpose of assessment is to provide decision-makers with the best valuable data, information, and predictions with which management decisions will be supported. In our examples, assessment deals with bivalves in different frameworks. One single study dealt with Ecosystem Services strictly speaking, and linked ES to marine habitats to identify ES availability and vulnerability to pressures. The results can be displayed as maps of resulting potential services with qualitative metrics (from low to high). The vulnerability value is an alternative to monetary valuation and, in addition to identifying the most suitable areas for each type of ES, this metric allows identifying the management strategies that will most probably maintain or affect each individual ES. In this example, bivalve farming and fishery are viewed as activities which take place in locations only defined by pressures and marine habitat features using a standard classification. Though qualitative, the indicators of ES availability and vulnerability can be used as a metric to compare ES and to assess how management strategies would affect the habitat's vulnerability for delivering ES.

It is interesting to note that this framework links to MSP, as illustrated in another example within approximately the same geographical region. In our example, MSP is focusing on bivalve farming activity and accounts for several criteria: habitat suitability, growth performance, environmental and regulation constraints and presence of other activities. The ultimate endpoint of such an approach is a map with qualitative values stating whether a location is suitable or not, depending on the weight given to each criterion. Though the output is limited to bivalve activity, it could be extended to all other activities and feed the ES framework as described in the previous example. Besides, this MSP approach only depicts site suitability (which relates to ES availability seen above) but does not directly give clues on the effect of management strategies.

However, none of these approaches accounts for more complex features related to system functioning. The two other examples clearly illustrate how interactions between some components of a system allow building of indicators of the sensitivity to changes. In the EA case study, the indicator is defined by the growth performance of cultivated bivalves in different locations. This indicator does not only depend on local conditions but is affected by distant factors - e.g. populations of marine organisms competing for the same food resource, nutrient inputs from rivers, time to renew water bodies under the action of tidal currents. These interactions portray a system made of variables, biological and physical processes and management scenarios. As for the previous examples, spatial distribution of these components is a key characteristic in the building of the indicator. In addition, the temporal dynamics and distant effects of factors are central to the assessment of the indicator responses to environmental changes or management decisions. In this example, management deals with measures regarding ecosystem health and aquaculture 
development - e.g. aquaculture extension, restoration of river quality, control of pest invasion. All these factors relate to the dynamics of a single primary resource (e.g. phytoplankton), which is shared by the main system components, resulting in trade-offs.

The existence of trade-offs and the definition of the appropriate spatial scale and resolution are keys to a policy-relevant assessment, which has been clearly exemplified by Nelson et al. (2009) in their modelling of multiple ecosystem services. In the example dealing with SAF, the scope shifted to account for the management of the freshwater resource and to integrate coastal zone and catchment areas. Since freshwater supply is the resource at stake for several activities (ecosystem preservation, drinking water, agriculture, bivalve culture), freshwater management units determines the system domain and spatial resolution. Regarding bivalves farming activity, the coastal zone is given as a single spatial unit for the sake of simplicity, and the endpoint is total annual production. It is worth noting that management rules are part of the system description and that, as for the EA case study, the connections between the components of the system drive the dynamics of the whole system in a set of cause-effect relationships.

\subsubsection{Methods and Tools}

Spatial data are essential for any assessment method. Tempera et al. (2016) provided an assessment of the spatial distribution of marine ecosystem service capacity in the European seas using habitat maps based on a EUNIS typology of marine habitats. Maes et al. (2012) reviewed current mapping methods, and identified current knowledge gaps to assess ES at European scales. Two of the gaps usually identified are the data quality and the capacity of data to inform on ecosystem functions. Both examples on MSP and ES illustrate how habitat mapping provides the first data layer to the assessment of ES, and how the combination of environmental data and information on human activities can inform MSP. Despite the gaps which have been outlined, more and more spatial data are being used to assess, directly or indirectly (e.g. proxies), biodiversity and ecosystem functions (Walters and Scholes 2016). In the field of aquaculture and fisheries, GIS and remote sensing data have been reviewed and promoted by Meaden and Aguilar-Manjarrez (2013). Therefore, the use of spatial data, combined with the tools and methods dealing with spatial and landscape ecology, and assessment tools such as InVEST, are promising.

Models have been central in some of our examples. Vulnerability assessment in the case of NBG relies on the calculation of indicators based on multidimensional input data regarding marine habitats, availability of ES and pressures due to human activities. In two other examples, bay of Mont Saint Michel and Pertuis Charentais, mathematical models have been set up to quantify the interactions between system components. In the first case, the model accounts for the ecological interactions between bivalve farming, primary productivity and wild benthic populations which are competing for the primary resource. In the second case, the primary resource 
was defined as the freshwater flow, which supports agriculture and primary production in the coastal zone. The model therefore accounts for several uses and also considers regulation rules. In both examples, the mathematical model allows the simulation of the dynamics of bivalve production, and scenarios have been setup with stakeholders to explore the response of bivalve yield to management options.

Models relate response to input variables. The choice between dynamic and statistical models depends on available data and system properties. Dynamic models must be preferred when the relationship between input and output variables may be masked by non-linear effects, delay of responses or differences of scales. The system is often multi-dimensional, and multiple variables would interact and affect the response of the system. It is also clear that spatial interactions must be taken into account and that spatial resolution depends on the issues addressed by the modelling approach. In the Pertuis Charentais example, spatial dimensions include the catchment area of the main river, and the coastal zone is defined as a single spatial entity. On the other hand, a high-resolution spatial model was set up in the Bay of Mont Saint Michel example to account for the competition between cultivated bivalves and wild populations of filter-feeders. Most important is the non-linear dynamics of most natural and human systems. Koch et al. (2009) noticed that most valuation processes assume that a quantity of an ecosystem function varies linearly with forcing variables. They suggest that understanding and quantifying nonlinearities in ecosystem functions would provide more realistic ES values. This is the reason why several approaches of ES assessment may be complementary and would need to be combined.

There is a debate regarding the economic methods that are most appropriate to support decision-making with respect to ecosystem management. The European Union Biodiversity Strategy to 2020 aims at assessing the economic value of ES, and promotes the integration of these values into accounting and reporting systems at EU and national levels by 2020 (Mongruel et al., in Cormier et al. 2013). However Balvanera et al. (2016, in Walters and Scholes 2016) stated that there are strong biases for economic values, "which are the product of markets and incentives, and do not necessarily account for the marginal contribution of ecosystems to food production through primary productivity, water for irrigation, soil fertility, pollination, or pest regulation, relative to those contributed by society. Also, these values do not include the negative impacts of agricultural intensification and expansion, nor that of industrial fisheries, on biodiversity conservation and the degradation of supporting and regulating". Monetary values are often of poor significance, especially for those ecosystem services whose loss could mean the end of life, and appear to be a comfortable oversimplification of reality of socio-ecological systems which cannot be summarized in single numbers (Mongruel et al., ibid.). Alternative methods would therefore consider institutional analysis or multicriteria assessment rather than only monetary values of ES. 


\subsubsection{Participatory Approach}

In most of our examples, stakeholders have been associated to the development of the assessment tools. In Normandy, stakeholder groups have been setup to identify the most critical issues in terms of aquaculture spatial planning. Lessons learned with MSP showed that stakeholders should be involved beforehand in the process to establish a dialogue, minimize conflicts of uses and avoid sectoral approaches. In the Bay of Mont Saint Michel study, the ecosystem model has been proposed as a tool to understand the main ecological interactions and to identify the main drivers of ecosystem carrying capacity. Stakeholders were consulted to define modelling scenarios, which were run to sort out the most effective management options with respect to bivalve biological production. Stakeholder involvement was also at the core of the System Approach Framework (SAF) in the Pertuis Charentais case study. Decision-makers contributed to the definition of the policy issue, the system characteristics, and regulation procedures. The development of the mathematical model resulted from this consultation process and the assessment of the model outputs was conducted with decision-makers.

In all our examples, the assessment tool could not be transferred to some administration, private company or national agency for further use. This poses some limitation on the maturity of the assessment approach, rather than the methods themselves. In a paper on carrying capacity assessment, Byron et al. (2011) outlined that a major gap in effective decision-making is due to poor communication between scientists and stakeholders. This fact has been turned into general principles (Byron et al. 2011): several categories of stakeholders must be involved (e.g. end-users, decision-makers, etc.); the stakeholder process should be conducted in an independent and unbiased way; stakeholders should be involved early in the process, should have an opportunity for input, have influence over the final decision; the stakeholder process and objectives should be transparent. One lesson learned from the SAF case study presented here is that collective thinking allows identification of issues, building system representation, and evaluation of the outputs of the assessment, and ensures the engagement of the stakeholders, the credibility and the acceptance of the assessment. This is specifically true when the assessment is based on models (Voinov et al. 2016).

Acknowledgements The work presented here has been partially supported by EU Horizon 2020 FPR 'Aquaspace' grant No. 633476. We are grateful for the comments of two referees on the manuscript. 


\section{References}

AAMP (2009) Analyse des enjeux et propositions pour une stratégie d'aires marines protégées Bretagne Nord /Ouest Cotentin. Agence des Aires Marines Protégées. 38 pp + annexes

Aguilar-Manjarrez J, Kapetsky JM, Soto D (2010) The potential of spatial planning tools to support the ecosystem approach to aquaculture. Expert. FAO Fisheries and Aquaculture Proceedings. No. $17,176 \mathrm{pp}$

Anderies JM, Janssen MA, Ostrom E (2004) A framework to analyze the robustness of socialecological systems from an institutional perspective. Ecol Soc 9(1):18

Blanchard M (1997) Spread of the slipper limpet (Crepidula fornicata) in Europe. Current state and consequences. Sci Mar 61:109-118

Blanchard M (2009) Recent expansion of the slipper limpet population (Crepidula fornicata) in the Bay of Mont-Saint-Michel (Western Channel, France). Aquatic Living Ressour 22:11-19

Brugère C, Ridler N, Haylor G, Macfadyen G, Hishamunda N (2010) Aquaculture planning: policy formulation and implementation for sustainable development. FAO Fisheries and Aquaculture Technical Paper No. 542, FAO, Rome, 70p

Byron C, Bengtson D, Cosat-Pierce B, Calanni J (2011) Integrating science into management: ecological carrying capacity of bivalve shellfish aquaculture. Mar Policy 35:363-370

Cabral P, Levrel H, Schoenn J, Thiébaut E, Le Mao P, Mongruel R, Rollet C, Dedieu K, Carrier S, Morisseau F, Daures F (2015) Marine habitats ecosystem service potential: a vulnerability approach in the Normand-Breton (Saint Malo) Gulf, France. Ecosyst Serv 16:306-318

Cormier R, Davies I, Kannen A (eds) (2013) Integrated coastal-zone risk management ICES Cooperative Research Report 320. 145 pp

Cugier P, Struski K, Blanchard M, Mazurié J, Pouvreau S, Olivier F, Trigui J, Thiébaut E (2010a) Assessing the role of benthic filter feeders on phytoplankton production in a shellfish farming site: Mont Saint Michel Bay, France. J Mar Syst 82:21-34

Cugier P, Frangoudes K, Blanchard M, Mongruel R, Pérez Agúndez JA, Le Mao P, Robin T, Fontenelle G, Mazurié J, Cayocca F, Pouvreau S, Olivier F (2010b) Impact des facteurs environnementaux et des pratiques conchylicoles sur la baie du Mont Saint-Michel et la production conchylicole. Etude de scenarii par modélisation. Programme Liteau 3. Rapport Final, 176 p. http://archimer.ifremer.fr/doc/00026/13707/

Douvere F (2008) The importance of marine spatial planning in advancing ecosystem based sea use management. Mar Policy 32:762-771

European Community (2000) Directive of the European Parliament and of the council 2000/60/ $\mathrm{EC}$, establishing a framework for community action in the field of water policy. $62 \mathrm{pp}$

Koch E, Barbier E, Silliman B, Reed D, Perillo G, Hacker S, Granek E, Primavera J, Muthiga N, Polasky S, Halpern B, Kennedy C, Kappel C, Wolanski E (2009) Non-linearity in ecosystem services: temporal and spatial variability in coastal protection. Front Ecol Environ 7:29-37

Liquete C, Piroddi C, Drakou EG, Gurney L, Katsanevakis S, Charef A, Egoh B (2013) Current status and future prospects for the assessment of marine and coastal ecosystem services: a systematic review. PLoS One 8(7):e67737. https://doi.org/10.1371/journal.pone.0067737

Lonsdale JA, Weston K, Barnard S, Boyes S, Elliott M (2015) Integrating management tools and concepts to develop an estuarine planning support system: a case study of the Humber Estuary, Eastern England. Mar Pollut Bull 100:393-405

Lubell M, Schneider M, Scholz JT, Mete M (2002) Watershed partnerships and the emergence of collective action institutions. Am J Polit Sci 46(1):148-163

Maes J, Egoh B, Willemen L, Liquete C, Vihervaara P, Schägner JP, Grizzetti B, Drakou EG, Notte AL, Zulian G, Bouraoui F, Luisa Paracchini M, Braat L, Bidoglio G (2012) Mapping ecosystem services for policy support and decision making in the European Union. Ecosyst Serv 1:31-39

Meaden GJ, Aguilar-Manjarrez J (eds) (2013) Advances in geographic information systems and remote sensing for fisheries and aquaculture, FAO fisheries and aquaculture technical paper no. 552. Rome, FAO, 425 pp 
MEA (2005) Ecosystem and human well being: synthesis, Millenium ecosystem assessment. Island Press, Washington, DC, 137 pp

Mongruel R, Prou J, Ballé-Béganton J, Lample M, Vanhoutte-Brunier A, Réthoret H, Pérez Agúndez J, Vernier F, Bordenave P, Bacher C (2011) Modeling soft institutional change and the improvement of freshwater governance in the coastal zone. Ecol Soc 16(4):15. https://doi. org/10.5751/ES-04294-160415

Nelson E, Mendoza G, Regetz J, Polasky S, Tallis H, Cameron R, Chan K, Daily G, Glodstein J, Kareiva P, Lonsdorf E, Naidoo R, Richetts T, Shaw M (2009) Bodiversity conservation, commodity production, and tradeoffs at landscape scales. Front Ecol Environ 7(1):4-11

Pinot JP (1998) L'outil par excellence de l'aménagement intégré du littoral: le SMVM, voeux pieux et réalités. In: Miossec A, Perron F (eds) Analyse et gestion intégrée des zones côtières, Seminaire de l'UMR 6554. CNRS, Nantes, pp 33-39, cited in Cormier et al. 2013

Rice J et al (2010) Science dimensions of an Ecosystem Approach to Management of Biotic Ocean Resources (SEAMBOR). Marine Board Position Paper 14

Tempera F, Liquete C, Cardoso AC (2016) Spatial distribution of marine ecosystem service capacity in the European seas. In: EUR 27843. Publications Office of the European Union, Luxembourg

Tett P, Sandberg A, Mette A (2011) Sustaining coastal zone systems. Academic Press, Dunedin, $173 \mathrm{pp}$

Voinov A, Kolagani N, Mccall M, Glynn P, Kragt M, Osermann F, Pierce S, Ramu P (2016) Modelling with stakeholders - next generation. Environ Model Softw 7:196-220

Walters M, Scholes R (eds) (2016) The GEO handbook on biodiversity observation networks. Springer Open, Cham, 326 pp

Open Access This chapter is licensed under the terms of the Creative Commons Attribution 4.0 International License (http://creativecommons.org/licenses/by/4.0/), which permits use, sharing, adaptation, distribution and reproduction in any medium or format, as long as you give appropriate credit to the original author(s) and the source, provide a link to the Creative Commons license and indicate if changes were made.

The images or other third party material in this chapter are included in the chapter's Creative Commons license, unless indicated otherwise in a credit line to the material. If material is not included in the chapter's Creative Commons license and your intended use is not permitted by statutory regulation or exceeds the permitted use, you will need to obtain permission directly from the copyright holder. 